\title{
CONSENSO E IMPOSICIÓN EN LA CONSERVACIÓN DE LA MONARQUÍA. LA PRÁCTICA POLÍTICA EN UN TERRITORIO DE LA PERIFERIA CASTELLANA: EL REINO DE MURCIA (1682-1700)*
}

\author{
por \\ JULIO D. MUÑOZ RODRÍGUEZ \\ Universidad de Murcia
}

RESUMEN: Durante muchos años se ha considerado la segunda mitad del siglo XVII como paradigma de la llamada "Decadencia Española». Pero detrás de ese tópico bistoriográfico aparecen bastantes sintomas para repensar esta coyuntura como creadora de unas bases socioeconómicas y políticas sobre las que se sustentarían los logros atribuidos al «reformismo borbónico». Tomando como modelo el reino de Murcia, abordamos la generación de un consenso político entre elites locales y Corona en un escenario de inestabilidad monárquica (sucesión de Carlos II) e institucional (no convocatoria de Cortes en Castilla). Sin embargo, la defensa de las fronteras de la Monarquía se tradujo en un perceptible incremento fiscal y en un desarrollo de nuevos instrumentos administrativos con los que bacer más efectiva la coerción sobre la población.

Palabras clave: Consenso político. Coerción. Corona. Elites locales. Servicio. Contraprestación. Reclutamiento. Reformismo Borbónico.

* Este trabajo ha sido realizado gracias a una beca FPI $(01572 / \mathrm{CV} / 01)$ y en el marco del Proyecto de Investigación Una sociedad ante la guerra: elección política, movilización y resistencias en el Reino de Murcia durante la Guerra de Sucesión (00650/CV/99), ambos financiados por la Fundación SénecaComunidad Autónoma de la Región de Murcia. El autor desea expresar aquí su especial agradecimiento a los profesores Francisco Javier Guillamón Álvarez y José Javier Ruiz Ibáñez. Las abreviaturas empleadas corresponden a: AGS (Archivo General de Simancas): GA (Guerra Antigua), CJH (Contadurías y Juntas de Hacienda), CC (Cámara de Castilla); AHN (Archivo Histórico Nacional): E (Estado), CS (Consejos); ACMS (Archivo Casa Medina Sidonia); AHPM (Archivo Histórico Provincial de Murcia); AMM (Archivo Municipal de Murcia): AC (Acta Capitular), AO (Ayuntamiento Ordinario), AE (Ayuntamiento Extraordinario), CR (Cartulario Real); y AML (Archivo Municipal de Lorca).

Hispania, LXIII/3, núm. 215 (2003) 969-994 
ABSTRACT: For many years, the second balf of the seventeenth century has been considered the paradigm of the so-called decadence of Spain. But there are many reasons to reconceptualize this period as one which saw the origin of new socio-economic and political foundations upon which the success attributed to Bourbon reforms would be based. Taking the kingdom of Murcia as a model, this article deals with a generation of political consensus between local elites and the Crown in a context of royal and institutional instability, relating to the succession of Carlos II and to the fact that the Cortes of Castile were not convened. The defence of the borders of the Monarchy meant a perceptible fiscal increase and the development of new administrative instruments to make coercion over the population more effective.

KEY WORDS: Political consensus. Coercion. Crown. Local elites. Service. Royal compensation. Recruitment. Bourbon reform.

A mi abuelo Francisco Muñoz, in memoriam

Aunque la identificación del último tercio del siglo XVII como paradigma clásico de la decadencia de la Monarquía hispánica comenzó a formarse con los escritos arbitristas de la misma época finisecular, no alcanzó un notable grado de generalización hasta algunas décadas después ${ }^{1}$. Fue con la publicística borbónica del siglo XVIII, iniciada a gran escala durante la Guerra de Sucesión ${ }^{2}$, así como con gran parte de la historiografía romántica y liberal, cuando este discurso historicista se elevó a categoría y terminó siendo asumido por un considerable, como ortodoxo, sector historiográfico hasta bien entrado el siglo $\mathrm{XX}^{3}$. No obstante, durante la década de 1980 una serie de trabajos empezaron

1 EGIDO, T.: Sátiras políticas de la España Moderna, Madrid, 1973, pp. 180-203; CÁRCELES DE GEA, B.: «Juicio y debate del régimen polisinodial en las campañas políticas del reinado de Carlos II» en Pedralbes. Revista de Historia Moderna (Barcelona) 7 (1987) pp. 103-125: y FERNÁNDEZARMESTO, F.: «Visiones del fin del siglo XVII en España» en CARR, R.: Visiones de fin de siglo, Madrid, 1999, pp. 65-92.

2 PÉReZ PICAZO, M. T.: La publicística española en la Guerra de Sucesión, Madrid, 1959; y los más recientes de ALABRÚS I IGLÉsIES, R. M.: Felip V i l'opinió dels catalans, Lleida, 2001, y GARCía CÁRCEL, R.: «La opinión de los españoles sobre Felipe V después de la Guerra de Sucesión» en Cuadernos de Historia Moderna (Madrid) Anejo I (2002) pp. 103-125.

${ }_{3}$ Nos referimos a una tradición iniciada por obras como la - muy válida por otras razonesde BaCallar y SANNA, V. (marqués de San Felipe): Comentarios de la Guerra de España e bistoria de su rey Felipe V, el Animoso, Génova, 1725, $1^{\text {a }}$ ed. [Ed. de Carlos Seco Serrano, Madrid, 1957], y continuada por las de CánOVAS DEl CASTILlo, A.: Historia de la decadencia de España, Madrid, 1854, y Bosquejo histórico de la Casa de Austria en España, Madrid, 1869 [reeditadas ambas en Málaga, 1992]; LAFUENTE Y ZAMALLOA, M.: La bistoria general de España desde los tiempos primitivos hasta la muerte de Fernando VII, Barcelona, 1883; JUDERíAS Y LOYOT, J.: España en tiempos de Carlos II el Hechizado, Madrid, 1912; PFANDL, L.: Carlos II. Madrid, 1947; o MAURA Y GAMAZO, G.: Vida y reinado de Carlos II, Madrid, 1954 [reed. Madrid, 1990].

Hispania, LXIII/3, núm. 215 (2003) 969-994 
a desmontar algunos mitos fabricados sobre el reinado del último Austria madrileño, y a señalar otros factores que, asimismo, se dieron en estos años finales del siglo XVII: unos primeros síntomas de recuperación demográfica ${ }^{4}$; un relevo en el protagonismo económico de la periferia mediterránea y cantábrica frente al desvanecido apogeo meseteño ${ }^{5}$ y el cultivo de un pensamiento crítico - los novatores - relacionado con los nuevos vientos racionales que soplaban desde el centro del Continente europeo ${ }^{6}$.

Hace algún tiempo, el mismo Pierre Vilar ya previno que la comprensión del reinado de Carlos II pasa más por las realizaciones efectuadas, que por el interés que pueda suscitar la desgraciada figura de un rey concreto ${ }^{7}$. Despojados ya de una amalgama de leyendas y desenfoques que ensombrecieron el carácter transicional y anticipativo a la época de los primeros Borbones, hemos empezado a conocer relativamente bien algunos aspectos de las incipientes políticas reformistas protagonizadas por una estimable generación de actores políticos que copó los puestos ejecutivos más destacados de la Corona; individuos, por cierto, sobre los que aún carecemos de unas pertinentes monografías que harían factible profundizar en esas razonables perspectivas de la coyuntura preborbónica, especialmente tras la etapa de don Juan José de Austria ${ }^{8}$. Menos dudas quedan, por el contrario, de las consecuencias estabilizadoras de la polí-

${ }^{4}$ Kamen, H.: La España de Carlos II, Barcelona, 1981, cap. IV; MOlas Ribalta, P.: «Reactivación y cambios sociales en los países de la Corona de Aragón y Castilla» en La transición del siglo XVII al XVIII, Madrid, 1993: Historia de España, dirigida por J. M. Jover Zamora, vol. XXVIII, pp. 551-655; y PÉREZ MOREDA, V. y REDHER, D. S.: «Población urbana española entre los siglos XVI y XVIII. Una perspectiva demográfica» en FORTEA PÉREZ, J. I. (ed.): Imágenes de la diversidad. El mundo urbano en la Corona de Castilla (s. XVI-XVIII), Santander, 1997, pp. 129-163.

s YUN CASAlilla, B.: "Del centro a la periferia: la economía española bajo Carlos II» en Studia Historica, Historia Moderna (Salamanca) 20 (2000) pp. 45-75.

6 En cuanto a los novatores remitimos al informe Los novatores como etapa bistórica de Studia Historica, Historia Moderna (Salamanca) 14 (1996); y LÓPEZ PIÑERO, J. M.: Ciencia y técnica en la sociedad española de los siglos XVI y XVII, Barcelona, 1979, esp. pp. 15-18 y 371-455. Sobre el contexto intelectual europeo sigue siendo referencia HAZARD, P.: La crisis de la conciencia europea, 1680-1.715, Madrid, 1975; una visión del mundo en WILLS, J. E.: 1688. Una historia global, Madrid, 2002.

7 VILAR, P.: Cataluña en la España moderna, Barcelona, 1987, $3^{\text {a }}$ ed. [ $1^{a}$ ed París, 1962], vol. 1, pp. 451-452.

8 Nos referimos a un Medinaceli, un Oropesa o a algunos otros representantes del sistema polisinodial; del mismo marqués de los Vélez ya llamó la atención el profesor Alcalá-Zamora sobre su impronta colbertiana en "Razón de Estado y geoestrategia en la política italiana de Carlos II: Florencia y los presidios (1677-81)» en Boletín de la Real Academia de la Historia (Madrid) 173 (1976) esp. p. 330; también se ha referido a estos primeros reformistas, ARTOLA, M.: La Hacienda del Antiguo Régimen, Madrid, 1982, pp. 216-222; RiBOT, L.: «La España de Carlos II» en La transición..., pp. 62-203; SANZ AYÁN, C.: «Reformismo y Real Hacienda: Oropesa y Medinaceli» en IGLESIAS, M. C. (Ed.): Nobleza y sociedad en la España Moderna, Oviedo, 1996, pp. 163-184, y BERNARdo ARES, J. M. de: «El conde de Oropesa. El antifranquismo como causa de un proceso político» en MUÑOZ MACHADO, S. (Ed.): Los grandes procesos de la Historia de España, Barcelona, 2002, pp. 172-192. 
tica monetaria9; las novedades centralizadoras impuestas desde el Consejo de Hacienda (desaparición de la Diputación del Reino y su integración en la Comisión de Millones $)^{10}$; la caracterización del sistema fiscal y el desarrollo de sus formas impositivas ${ }^{11}$; los instrumentos financieros de los que se sirvió el mismo Erario carolino ${ }^{12}$; o el hecho de unas paradójicas alianzas internacionales de una Monarquía asediada en tierra y mar por la entonces considerada potencia hegemónica europea, la Francia de Luis XIV ${ }^{13}$.

Pero si el interés, como se puede comprobar, se ha puesto más bien en el factor económico-fiscal, el grado de aceptación social de estas reformas carolinas - nada ingenuas y siempre tratando de elevar el nivel de coerción ejercido- apenas se ha esbozado. Como muy desdibujada queda todavía la interrelación entre Corona y territorios castellanos en un momento de notable cohesión monárquica de unas elites provinciales menos movilizadas en sus discursos y prácticas políticas por unos valores republicanos ${ }^{14}$; posición que, ade-

9 Desde el trabajo pionero de Collantes Pérez-Ardá, E. y Merino Navarro, J. P.: «Alteraciones al sistema monetario de Castilla durante el reinado de Carlos II» en Cuadernos de Investigación Histórica (Valladolid) 1 (1977) pp. 72-98, al de SÁNCHEZ BELÉN, J. A.: «Arbitrismo y reforma monetaria en tiempos de Carlos II» en Espacio, Tiempo y Forma (Madrid) serie IV-5 (1992) pp. 135175; los orígenes de este recurso hacendístico en GARCía GUERRA, E. M.: Las acuñaciones de moneda de vellón durante el reinado de Felipe III, Madrid, 1999.

10 CÁRCELES DE GEA, B.: Reforma y fraude fiscal en el reinado de Carlos II. La Sala de Millones (1658-1700), Madrid, 1995, pp. 33-42 y 123-128; y CastellanO, J. L.: Las Cortes de Castilla y su Diputación (1621-1789). Entre pactismo y absolutismo, Madrid, 1990, pp. 85-112.

1 SÁNCHEZ BeLÉN, J. A.: La política fiscal en Castilla durante el reinado de Carlos II, Madrid, 1996; ANDRÉs UCENDO, J.I.: La fiscalidad en Castilla en el siglo XVII: Los servicios de Millones, 1601 1700, Bilbao, 1999, y "La fiscalidad castellana en el siglo XVII" en Le forze del Principe. Risorse, strumenti e limiti nella pratica del potere sourano nei territori della Monarchia asburgica (en prensa), además de la visión general que ofrece DUBET, A.: «Finances et réformes financières dans la monarchie espganole, mi-XVI ${ }^{\mathrm{e}}$-début XVIII siècle» en Bulletin de la Société $d^{\prime}$ 'Histoire Moderne et Contemporaine (París) 3-4 (2000) pp. 56-83.

${ }_{12}$ Una síntesis en Garzón Pareja, M.: La Hacienda de Carlos II, Madrid, 1980; sobre los asentistas, VALLADARES, R. Banqueros y Vasallos. Felipe IV y el medio general, Cuenca, 2002; y SANZ AYÁN, C.: Los banqueros de Carlos II, Valladolid, 1988.

${ }^{13}$ STRADling, R. A.: España y el declive de la estructura imperial española, 1580-1720, Madrid, 1983, esp. pp. 229-262; HERRERO SÁNCHEZ, M.: El acercamiento bisponao-neerlandés (1648-1678), Madrid, 2000, esp. parte IV; SÁNCHEZ BELÉN, J. A.: «Las relaciones internacionales de la Monarquía hispánica durante la Regencia de doña Mariana de Austria» en Studia Historica, Historia Moder$n a$ (Salamanca) 20 (2000) pp. 137-172; HUGON, A.: «Des Habsbourg aux Bourbons: le combat espagnol pour la conservation de l'hégémonie européene: milieu XVI'-fin XVII siècle» en Bulletin de la Société d'Histoire Moderne et Contemporaine (París) 3-4 (2000) pp. 34-55.

${ }_{14}$ En un sentido general ha sido planteada por THOMPSON, I. A. A.: «La movilización de los recursos nacionales y la tesis de Downing. La guerra y el Estado en España a mediados del siglo XVII» en MARTínez Ruiz, E. y PAZZIS PI Corrales, M. DE (dirs.): España y Suecia en la época del Barroco (1600-1660), Madrid, 1998, pp. 279-306; para otros territorios específicos de la Monarquía, RuIZ IBÁÑEZ, J. J.: «Tiempo de guerra, tiempo de cambio. Resistencias, realidades y representaciones en los comienzos de la transición al pleno absolutismo en el Reino de Murcia (1642-1669)» 
más, coincide en la Corona de Aragón con esa convergencia de intereses que en el fondo representó el tan debatido neoforalismo, concepto acuñado por Reglá en la década de $1950^{15}$. No mucha más atención ha recibido el desarrollo de una gama variable de agentes reales, entendidos como pilares de un proceso de centralización administrativa, consecuente más con la búsqueda de una eficacia ad boc, que con la puesta en práctica de un consciente programa uniformizador o absolutista ${ }^{16}$; al igual que ha ocurrido con el tránsito profesional-familiar de las milicias locales hacia unos cuerpos armados más subordinados al control del aparato monárquico. Todas estas cuestiones resultan ineludibles si pretendemos observar este periodo bajo unas amplias dimensiones que reúnan los ingredientes de continuidad asimilados por un ecléctico reformismo borbónico — cuyas raíces podrían llegar a alcanzar el aplazado programa olivarista - y hagan relegar la excepcionalidad de la España de Carlos II dentro del contexto europeo de fortalecimiento y extensión de la potestas regia ${ }^{17}$. Muy posiblemente la Corona que heredó Felipe V se servía ya entonces, usando la terminología de Koenigsberger, de un dominium más regale que politicum, a pesar del acatamiento esencial a cada una de las peculiaridades constitucionales de la Monarquía, cuyo reflejo consistió en la conformación de

en Le forze del Principe... (en prensa), y Álvarez-Ossorio Alvariño, A.: La República de las parentelas. El Estado de Milán en la monarquía de Carlos II, Mantua, 2002, esp. parte IV.

15 Entre la ya abundante bibliografía entorno al neoforalismo destacamos, SÁNCHEZ MARCOS, F.: Cataluña y el gobierno central tras la Guerra de los Segadores. El papel de don Juan José de Austria en las relaciones entre Cataluña y el gobierno central, 1652-1679, Barcelona, 1983, TORRAS i RIBÉ, J. M.: "Una imatge crítica del neoforalisme: el control polític de les insaculacions de Barcelona a finals del segle XVII» en $L$ 'Avenç (Barcelona) 184 (1994) pp. 30-35; GIL PUJOL, X.: "La cultura política de la Corona de Aragón a finales del siglo XVII. A vueltas con el neoforalismo» en FerNÁNDEZ ALBALADEJO, P.: Los Borbones. Dinastía y memoria de nación en la España del siglo XVIII, Madrid, 2001, pp. 97-115; y Álvarez OSORIO AlvariÑo, A.: «Neoforalismo y Nueva Planta. El gobierno provincial de la Monarquía de Carlos II en Europa» en Alcalá-Zamora, J. y Belenguer, E. (Coords.): Calderón de la Barca y la España del Barroco, Madrid, Vol. 1, 2001, pp. 1061-1089. También, SANZ CAMAÑEs, P.: Política, Hacienda y Milicia en el Aragón de los últimos Austrias entre 1640 y 1680, Zaragoza, 1997; Passola, A.: Oligarquía i poder a la Lleida dels Austria. Una elit municipal catalana en la formació de l'Estat Modern, Lérida, 1997; y CANET APARISI, T.: «Los apuros del Rey» en Estudis. Revista de bistoria moderna (Valencia) 24 (1998) pp 185-202.

${ }^{16}$ El debate sobre este término puede seguirse en las aportaciones de Henshall y Hinrinchs reunidas en AsCH, R. G. y DuchaRDT, H. (Edits.): El Absolutismo ¿Un mito?. Revisión de un concepto bistoriográfico clave, Barcelona, 2000, pp. 43-107.

17 Las raíces implícitas del reformismo borbónico en este periodo las han señalado recientemente Gulllamón AlvareZ, F. J.: «La Guerra de Sucesión y el comienzo de las reformas borbónicas» en Fernández García, J., Bel Bravo, M. A. y Delgado BARRADo, J. M. (Edits.): El cambio dinástico y sus repercusiones en la España del siglo XVIII. Homenaje al doctor Luis Coronas Tejada, Jaén, 2000, pp. 529-542; y SAN MARTín PÉREZ, E.: La instauración de la Monarquía borbónica en España, Madrid, 2001. Referente al estereotipo de la excepcionalidad política y económica españolas, RINGROSE, D. R.: España, 1700-1900: el mito del fracaso, Madrid, 1996; también ELLIOTT, J. H: «Europa después de la Paz de Westfalia» en Pedralbes (Barcelona) 19 (1999) pp. 131-146; y ScHAuB, J. F.: "Autour de la question absolutiste: regards croisés sur la France et l'Espagne» en Bulletin de la Société d'Histoire Moderne et Contemporaine (París) 3-4 (2000) pp. 3-16. 
un equilibrio cada vez más escorado - «oblicuo» lo ha denominado García Cárcel- hacia la primera de estas terminales políticas ${ }^{18}$.

Intentar contestar a estas incertidumbres requiere descender al terreno de la práctica política, y observar la implicación de distintas y superpuestas esferas de poder; sólo así podremos llegar a obtener una comprensión de conjunto que nos aporte más razones para desterrar pasadas concepciones unívocas. En nuestro caso, nos serviremos del modelo que ofrece un territorio de esa periferia mediterránea de la Monarquía: el reino de Murcia ${ }^{19}$, un espacio político fagocitado por su capital que se erigía en la interlocutora visible ante la Corona, la portavoz institucional de todo el reino - uno de los veintiún votos en las Cortes castellanas del momento- y en la referencia fiscal para su heterogénea población ${ }^{20}$.

\section{LA RELACIÓN CORONA-REINO: EL CONSENSO COMO IMPOSICIÓN, LA IMPOSI- CIÓN COMO CONSENSO}

Desde 1665 la población de la Corona de Castilla asistió a un progresivo establecimiento de nuevos usos en el ejercicio del poder. Si bien, a lo largo de la segunda mitad del reinado de Felipe IV, ya se fueron introduciendo perceptibles innovaciones administrativas (la integración de la Comisión de Millones en el Consejo de Hacienda (1658) o la aparición de numerosos ejecutores y delegados especiales del rey son buena prueba de ello ${ }^{21}$ ), el mantenimiento de las urgencias hacendísticas durante las últimas cuatro décadas del siglo XVII favoreció la asimilación e impulso de otras modificaciones jurisdiccionales. La inestabilidad estructural de la Monarquía hispánica —una incierta sucesión y varios tratados de reparto ${ }^{22}$ - no conllevó, en este sentido, un freno a esos

18 Koenigsberger, H. G.; «Dominium regale o dominium politicum et regale. Monarquías y parlamentos en la Europa Moderna» en Revista de las Cortes Generales (Madrid) 3 (1984) pp. 87-120; y GARCÍA CÁRCEL, R: Felipe $V$ y los españoles. Una visión periférica del problema de España, Barcelona, 2002b, esp. pp. 39-53.

19 Su inserción en esa periferia emergente en Pérez PICAZo, M. T. y Lemeunier, G.: El proceso de modernización en la Región Murciana (siglos XVI-XX), Murcia, 1984, pp. 108-120.

${ }^{20}$ Gulllamón Álvarez, F. J. y Ruiz IbÁÑEz, J. J.: «Discurso político y redefinición jurisdiccional en la Castilla de Felipe II: la construcción del Reino de Murcia» en BELENGUER CEBRIÁ, E.: Felipe Il y el Mediterráneo, Madrid, 1999, pp. 481-499.

${ }^{21}$ CÁRCELES DE GEA, B.: Fraude y administración fiscal en Castilla. La Comisión de Millones (16321658),Madrid, 1994, y «Del juez de comisión al comisario real (1632-1643). El fraude fiscal como agente del gobierno económico» en Studia Histórica. Historia Moderna (Salamanca) XIII (1995) pp. 155-175; y RuIz IBAÑEZ, J. J.: Las dos caras de Jano. Monarquía, ciudad e individuo. Murcia, 15881648, Murcia, 1995, pp. 300-309. También, GELABERT, J.: La bolsa del rey. Rey, reino y fisco en Castilla (1598-1648), Barcelona, 1997; y en especial Castilla convulsa (1631-1652), Madrid, 2001.

22 VICENT LÓPEZ, I.: «Entre prudentes y discretos. La conservación de la Monarquía Católica ante el Tratado de Repartición de 1700" en Espacio, Tiempo y Forma, Serie IV (Madrid) 9 (1996) pp. 323-337. 
movimientos coyunturales de adaptación. También es verdad que la predisposición política de la Corona había derivado hacia posiciones más contemporizadoras: la necesidad de negociación, de colaboración con las elites locales, era para entonces un valor no sólo teórico sino un habitual principio asumido en el ejercicio cotidiano del poder regio. De hecho, en un plano ideológico se había derivado del discurso político de «reducir estos reinos a uno» que había promovido el conde-duque de Olivares en su Gran Memorial de 1624, a una defensa de la colaboración entre las provincias y la Corona en la salvaguarda de la Monarquía, expuesta por don Juan de Palafox y Mendoza en su Juicio interior y secreto de la Monarquía para mí solo $(1665)^{23}$. Desde la misma Corte se era consciente que, siguiendo este camino pragmático, el objetivo de la conservación territorial de la Monarquía se hacía más accesible.

Las cortes que juraron a Carlos II fueron las últimas que se convocaron en Castilla hasta la expresión de fidelidad que se otorgó a Felipe V en $1701^{24}$. La ausencia de cualquier otra visualización conjunta del Reino durante un periodo tan prolongado se plasmó en el desarrollo de una más activa relación entre la Corona y los vasallos y en una novedosa formulación de la concesión de servicios económicos y personales. La maduración de un sistema de mutua dependencia entre Corona y mediadores locales venía a adquirir su naturaleza en la ruptura paccionada con la tradicional representación de las ciudades castellanas y en la transición hacia un modelo político donde se primaba el consenso de la coerción fiscal y la activa colaboración con las instancias provinciales. El incremento de capital extraído sería gestionado por unos concejos castellanos poseedores de una amplia autonomía, derivadá también de su probada eficacia como autoridad intermediaria ${ }^{25}$.

No obstante, esa transferencia fiscal iba a desembocar a largo plazo en otras consecuencias paralelas: si bien se lograba por parte de las ciudades un

${ }^{23}$ Elliott, J. H.: El conde-duque de Olivares. El político en una época de decadencia, Barcelona, 1990, pp. 191-212 y GARCíA CÁRCEL, R.: op. cit., 2002b, p. 31.

${ }^{24}$ Sobre el fin de las mismas, Castellano, J. L.: op. cit., pp. 69-84, THOMPson, I. A. A.: «El final de las Cortes de Castilla» en Revista de las Cortes Generales (Madrid) 8 (1986) pp. 8-66, y GIL Pujol, X.: «Las Cortes de Aragón en la Edad Moderna: comparación y reevaluación» en Revista de las Cortes Generales (Madrid) 22 (1991) pp. 79-119; el progresivo sometimiento al poder de la Corona en JAGO, Ch.: «Habsburg Absolutism and the Cortes of Castile» en The American Historical Review (Nueva York) 86-2 (1981) pp. 307-326, y ForTEA PÉrez, J. I.: «Las ciudades, las Cortes y el problema de la representación política en la Castilla Moderna» en Imágenes de la diversidad..., pp. 421-445; las conexiones olivaristas en Fernández Albaladejo, P.: Fragmentos de Monarquía, Madrid, 1992, pp. 333-337.

${ }^{25} \mathrm{El}$ modelo del que deriva, así como la definición de los conceptos, en RUIZ IBÁÑEZ, J. J.: «Una propuesta de análisis de la administración en el Antiguo Régimen: la Constitución Implícita Factual» en Ius Fugit. Revista interdisciplinar de estudios bistórico-jurídicos (Zaragoza) 3-4 (1994-1995) pp. 169-191. La primera fase de este proceso para el modelo murciano en GUILLAMÓN ÁlvarEZ, F. J., Ruiz IbÁÑ̃ez, J. J. y GarCía HourCADE, J. J.: La Corona y los representantes del Reino de Murcia (1590-1640): Necesidad, negociación, beneficio, Murcia, 1995.

Hispania, LXIII/3, núm. 215 (2003) 969-994 
beneficioso escenario caracterizado por la confusa relación formal y el aparente debilitamiento del poder de la Corona, ésta conseguía establecer nexos directos con las elites provinciales y ensanchar sus mecanismos coercitivos (recaudación económica, reclutamiento militar). Las nuevas competencias que, en principio, acapararon los órganos municipales, siempre podrían ser reasumidas legítimamente por la Corona al responder a una mera delegación regia; para entonces, esos cuerpos oligárquicos, esencialmente dependientes del patronazgo regio para mantener su preponderancia social, no ofrecerían grandes resistencias ante posibles soluciones más ejecutivas ${ }^{26}$. Esto, que fue precisamente el mérito del reformismo borbónico durante y después de la Guerra de Sucesión, ya es detectable algunas décadas antes ${ }^{27}$.

Desde finales del siglo XVI los concejos de capitales de provincia, los mismos que poseían el privilegio de voto en cortes, habían profundizado en su carácter de cabezas de partido con la asignación de las funciones inspectoras que a nivel provincial les reservaba las condiciones del servicio de Millones, seguramente el de mayor cuantía de la Hacienda real castellana ${ }^{28}$. Pero, al mismo tiempo, esta actitud cooperadora — que se iba a fomentar desde la dificil década de 1630 - otorgaba a estas instituciones patrimonializadas una ubicación predominante como interlocutoras de la Corona; la inversión adecuada de este capital político se tradujo para sus integrantes de voz y voto - los regidores- en un importante instrumento en el que apoyar solicitudes de merce-

${ }^{26}$ SCHIERA, P.: «Legittimità, disciplina, istituzioni: tre presupposti per la nascita dello Stato moderno» en Origini dello Stato. Processi di formazione statale in Italia fra medioevo ed età moderna, Bolonia, 1994, pp. 17-48, y HESPANHA, A. M.: «Paradigmes de légitimation, aires de gouvernement, traitement administratif et agents de l'administration» en DescimON, R. SCHAUB, J. F. y VINCENT, B. (Dirs.): Les figures de l'administrateur. Institutions, réseaux, pouvoirs en Espagne, en France et au Portugal, 16 $-19^{\circ}$, París, 1997, pp. 19-28. Los lazos de dependencia de las elites provinciales con la Corona en THOMPSON, I. A. A.: «Patronato real e integración política en las ciudades castellanas bajo los Austrias» en ForTeA PÉreZ, J. I. (ed.): op. cit., 1997, pp. 475-496, y GarCía HourCADE, J. J. y RUIZ IBÁÑEZ, J. J.: «Un poder simbiótico: la articulación de los lazos de dependencia entre la Corona y los mediadores, Murcia ss. XVI y XVII» en GUILLAMÓN ÁllVAREZ, F. J. y RUIZ IBÁÑEZ, J. J. (eds.): Lo conflictivo y lo consensual en Castilla. Sociedad y poder politico, 1521-1715. Homenaje a Francisco Tomás y Valiente. Cuaderno del Seminario Floridablanca, $n^{0} 4$, Murcia, 2001, pp. 401-437.

27 Durante el conflicto bélico, KAMEN, H.: La Guerra de Sucesión en España, 1700-1715, Barcelona, 1974, esp. pp. 47-68 y 99-135, y FERNÁNDEZ AlBALADEJO, P.: op. cit., 1992, pp. 380-412; asimismo, a nivel municipal, GUILlAMÓN ÁLVAREZ, F. J.: «The institutional reform and Municipal Government in the Spanish Eighteenth Century» en Itinerario. European Journal of Overseas History (Leiden) 3 (1996) pp. 109-124; en la administración central, a modo de ejemplo, CASTRO, C. de: «El Estado español en el siglo XVIII: su configuración durante los primeros años del reino de Felipe V» en Historia y política. Ideas, procesos y movimientos sociales (Madrid) 4 (2000/2) pp. 137-169.

${ }^{28}$ FORTEA PÉREZ, J. I.: «Reino y Cortes: el servicio de millones y la reestructuración del espacio fiscal de la Corona de Castilla (1601-1621)» en Politica y Hacienda en el Antiguo Régimen, Murcia, 1993, pp. 53-83; ANDRÉs UCENDO, J. I.: op. cit., 1999, pp. 43-44; y THOMPSON, I. A. A.: «Castilla, España y la Monarquía: la comunidad política, de la Patria natural a la Patria nacional» en España, Europa y el mundo Atlántico. Homenaje a Jobn H. Elliott, Madrid, 2001, pp. 177-216, esp. 206-211. 
des al monarca ${ }^{29}$. De este modo, tanto hábitos, encomiendas, ciertos nombramientos administrativos — significativamente los corregimientos-, como títulos nobiliarios, representaron la particular contraprestación del monarca a unas elites castellanas que, aunque diferían en el nivel de propiedad simbólica, participaban en un sistema que incentivaba y aceleraba la reciprocidad política ${ }^{30}$.

Ejemplo de esta creciente identificación con los intereses de la Corona nos lo ofrece la ciudad de Murcia. El concejo murciano fortaleció durante las últimas décadas del siglo XVII su carácter de institución aglutinadora de decisión política y portavoz de unos intereses que iban más allá a los intrínsecos a su oligarquía natural. Las superiores expectativas de beneficio personal que implicaba la pertenencia a una de las ciudades de voto puso al descubierto estrategias de inserción desde otras oligarquías locales del reino de Murcia, estrategias que trataron de ser contrarrestadas por los tradicionales linajes patricios mediante intentos de cierre corporativo ${ }^{31}$. Sólo cuando fracasaron estos planteamientos colectivos se pusieron en práctica otras movimientos defensivos de carácter más circunscrito, fuese vía intitulación o cualquier otra capaz de exteriorizar y mantener una diferenciación social que había ido devaluándose con el tiempo. A esto responde el deseo de titularse de linajes patricios como los Fontes de Albornoz, Molina de Junterón o Roda - propósito, en algunos de ellos, no materializado hasta la Guerra de Sucesión-, que no constituyen más que el ejemplo murciano de una tendencia general que favoreció el fuerte engrosamiento de estos estratos de la nobleza urbana castellana ${ }^{32}$.

${ }^{29}$ HERnÁNDEZ BENÍteZ, M.: «Cuando el poder se vende: venta de oficios y poder local» en Alvarado, J. (Coord.): Poder, economía, clientelismo, Madrid, 1997, pp. 71-95; la función redistribuidora del monarca en DIOS, S. DE: Gracia, merced y patronazgo real. La Cámara de Castilla entre 1474-1530, Madrid, 1993, pp. 69-121; CÁRCELES DE GEA, B.: «La justicia distributiva en el siglo XVII (Aproximación político-constitucional)» en Chronica Nova (Granada) 14 (1984-1985) pp. 93122; la generación de estas expectativas en las ciudades con voto conllevó el deseo en otras de alcanzar este privilegio, por ejemplo, Jerez: GONZÁLEZ BELTRÁN, J. M.: «La representación del Reino en almoneda. Compra de voto en Cortes en el siglo XVII: el intento frustrado de Jerez de la Frontera» en Chronica Nova (Granada) 24 (1997) pp. 121-148.

${ }^{30}$ Para una interpretación antropológica de este concepto, ITURRA, R.: «O conceito de reciprocedade» en CARDESÍN, J. M. y RUIZ IBÁÑEZ, J. J.: Las relaciones entre teoría y práctica política, Seminario interdisciplinar (Murcia, 26-27 de noviembre de 2001) en prensa.

${ }^{31}$ Hernández Franco, J.: «Limpieza y nobleza en las ciudades de Castilla: pretensiones y consecución del privilegio de estatuto por parte de Murcia (1560-1751)» en Revista de Historia Moderna. Universidad de Alicante (Alicante) 17 (1998-1999) pp. 249-262.

${ }^{32}$ SORIA MESA, E.: El cambio inmóvil. Transformaciones y permanencias en una elite de poder (Córdoba, ss. XVI-XIX), Córdoba, 2001, pp. 101-113; Hernández BeníteZ, M.: A la sombra de la Corona. Poder local y oligarquía urbana (Madrid, 1606-1808), Madrid, 1995, pp. 64-70; GUTIÉRrEZ ALONSO, A.: Estudio sobre la decadencia de Castilla. La ciudad de Valladolid en el siglo XVII, Valladolid, 1989, pp. 301-315; o SALGADO OlmEDA, F.: «Tipología social de una oligarquía urbana: los regidores de Guadalajara en el siglo XVIII. ¿Elite nobiliaria o burguesía funcionarial?» en Hispania (Madrid) 211 (2002) pp. 693-746. Referente al ejemplo murciano, CHACÓN JIMÉNEZ, F.: «Hacia 
En el fondo, lo que se estaba produciendo en el conjunto de Castilla, como reflejo de lo que ya estaba sucediendo en otras partes de Europa ${ }^{33}$, era una reformulación del papel de esta nobleza urbana desde su inicial concepción republicana a una adaptación como verdadero agente del poder central, propiciada por la realidad de una insuficiente burocracia monárquica distribuida por todo el territorio ${ }^{34}$. Cuando esa incompleta red administrativa comenzase a multiplicarse - como sucedió desde mediados del siglo XVII con superintendentes y gobernadores-, la hegemonía de esta nobleza media castellana se vería afectada y la salida natural vendría dada con una progresiva marcha a la corte donde intensificar ese servicio a la Corona. Desde ese instante, quedarían perfeccionados unos mecanismos informales de movilización que implicaban al conjunto de la población con las demandas del aparato cortesano ${ }^{35}$. Mientras tanto, los nexos de unión de este patriciado urbano se manifestaría en la administración de una carga fiscal, que reportaba importantes beneficios individuales o familiares, como sucedía, particularmente, después de cada prorrogación del servicio de Millones con la generosa concesión de hábitos de órdenes militares $^{36}$; junto a la tolerancia de una adicional detracción impositiva, que tomaría forma en un reclutamiento sensiblemente más coercitivo, unos cuantiosos arbitrios o por medio de los propios recursos de las haciendas locales ${ }^{37}$.

una redefinición de la estructura social en la España del Antiguo Régimen a través de la familia y las relaciones de parentesco» en Historia Social (Valencia) 21 (1995) pp. 75-104.

${ }_{33} \mathrm{Al}$ respecto, MonTeIRo, N. G.: «Noblesse et aristocratie au Portugal sous l'Ancien Régime (XVII ${ }^{\mathrm{e}}$-debut du XIX ${ }^{\mathrm{e}}$ siècle)» en Revue d'Histoire Moderne et Contemporaine (París) 46-1 (1999) pp. 185-210; CARDIM, P.: «Memoria comunitaria y dinámica constitucional en Portugal (1640-1750)» en Fernández Albaladejo, P. (Ed.): op. cit., 2001, pp. 117-140; y KeTtering, S.: «The historical Development of Political Clientelism» en Journal of Interdisciplinary History (Cambridge) 18-3 (1988) pp. 419-447. Este fenómeno ya venía implícito en la clásica obra de STONE, L.: La crisis de la aristocracia, 1558-1641, Madrid, 1976, pp. 219-232.

${ }^{34}$ REINHARD, W.: «Élites du pouvoir, serviteurs de l'Etat, classes dirigeantes et croissance du pouvoir d'État» y DESCIMON, R: «Les élites du pouvoir et le prince: l'État comme entreprise» ambos en Les élites du pouvoir et la construction de l'État en Europe, París, 1996, pp. 1-24 y 133-162, respectivamente; también TпLY, C.: Coerción, capital y los Estados europeos, 990-1990, Madrid, 1990, pp. 87-91.

35 MONTEMAYOR, J.: «De las Cortes a la Corte. Oligarquías municipales y Monarquía (16501700)" en CASTELlano, J. L. (Ed.): Sociedad, administración y poder en la España del Antiguo Régimen. Hacia una nueva Historia institucional, Granada, 1996, pp. 237-251; SANZ CAMAN̄ES, P.: «Del reino a la corte. Oligarquías y elites de poder en las cortes de Aragón a mediados del siglo XVII» en Revista de Historia Moderna. Universidad de Alicante (Alicante) 19 (2001) pp. 205-238; ÁlvAREZ-Ossorio AlvARIÑO, A.: «El arte de medrar en la corte: rey, nobleza y el código del honor» en CHACóN JiMÉNEZ, F. y Hernández Franco, J. (Edits.): Familia, poderosos y oligarquías, Murcia, 2001, pp. 39-60; y RUIZ IBÁÑEZ, J. J. y MUÑOZ RODRíGUEZ, J. D.: «Sirviendo a la Corte en la aldea, sirviendo a la aldea en la corte: veteranos, agentes y medios de relación en el siglo XVII castellano» en BRAVO, J. (Ed.): Espacios de poder: Cortes, ciudades y villas, Madrid, 2002, T. II, pp. 227-247.

${ }_{36}$ MuÑoz Rodríguez, J. D.: Damus ut des. Los servicios de la ciudad de Murcia a la Corona a finales del siglo XVII, Murcia, 2003, pp. 98-102.

37 BERNARDO ARES, J. M. DE: Corrupción política y centralización administrativa. La Hacienda de propios en la Córdoba de Carlos II, Córdoba, 1993, cap. V; sus consecuencias en el siglo XVIII en

Hispania, LXIII/3, núm. 215 (2003) 969-994 


\section{COERCIÓN, MEDIACIÓN Y BENEFICIO: LA DEFENSA DE LAS FRONTERAS DE LA MONARQUía}

La naturaleza de frontera del litoral mediterráneo había ido adaptándose con el devenir de los siglos y las alianzas internacionales, pero aún a finales del siglo XVII se resistía a quedar en un mero recuerdo de tiempos pasados. La costa del Mediterráneo peninsular y en concreto la que ocupaba el reino de Murcia, se traducía en un escenario de enfrentamiento con las naves berberis$\operatorname{cas}^{38}$, conflicto que se volvía aún más tangible en el caso de las distintas plazas norteafricanas, como era el caso de Orán ${ }^{39}$. A la cotidianidad de las acciones corsarias, se añadía los circunstanciales contendientes de la Monarquía, que a lo largo del reinado de Carlos II procederían básicamente del peligro representado por las armadas francesas: sólo entre 1691 y 1694 se previnieron nueve veces a las milicias del reino de Murcia, de las que cuatro terminaron en un socorro efectivo a la ciudad de Cartagena. De este modo, el litoral murciano siguió encarnando un atractivo teatro bélico donde hacer realidad meritorios vínculos con la Monarquía. Así, al menos, lo entendían los regidores de la capital al intentar monopolizar las capitanías de las compañías ciudadanas/parroquiales, que tradicionalmente habían estado aparejados a los jurados: a su capacidad para proyectar servicios militares a la Corona de probable contraprestación, se unía la relativa peligrosidad que conllevaba para el vasallo ${ }^{40}$.

Ante la falta de una adecuada presencia de soldados profesionales, la defensa de la costa recaía en unas tropas semiprofesionales en claro retroceso. En la ciudad de Murcia las dos compañías de milicia general apenas alcanzaban normalmente el $20 \%$ de sus 300 hombres, debido a deserciones, labores agrícolas $y$, en general, al escaso interés lucrativo que en esos momentos entrañaban ${ }^{41}$. Por el contrario, mayor poder de convocatoria mantenían las unidades integra-

GARCíA GARCÍA, C.: La crisis de las haciendas locales. De la reforma administrativa a la reforma fiscal (1743-1845), Valladolid, 1996.

38 AGS GA 3070, sn: Cartagena, 30-IX-1697: don Tomás Pelerán (gobernador interino) al Consejo, sobre el combate frente a la torre del Estacio; o protagonizando auténticas batallas navales con las galeras de la Armada, 2721, sn: Cartagena, 23-IX-1686: el duque de Veraguas al marqués de Monreal (presidente del Consejo); en todo caso, suponía una causa de inseguridad tolerada por unos vecinos del campo conocedores del riesgo de que «los moros [puedan] saltar en tierra y molestarlos cautivarlos robarlos y matarlos [...]», AMM AC 1687, AO 22-II-1687.

39 ALONSO ACERO, B.: Orán-Mazalquivir, 1589-1639: Una sociedad española en la frontera de Berbería, Madrid, 2000, esp. pp. 193-202.

40 MUÑOZ RODRíGUEZ, J. D.: op. cit., pp. 143-144.

${ }^{41}$ AGS GA 2680, sn: Murcia, 27-II-1685: la ciudad a don Juan Antonio López de Zárate (presidente del Consejo), 2781, sn: Murcia, 15-VI-1688: los mismos; 3033, sn: Murcia, 10-IV1696: la ciudad al marqués del Solar (presidente del Consejo), y 3096, sn: Murcia, 21-I-1698: la ciudad a don Juan de Moral y Tejada; para medidas coactivas a los insumisos, AMM AC 1687 AO 19-VII-1687; AC 1688 AO 15-V-1688; y AC 1693 AO 28-VII-1693. Sobre la milicia general y su implantación a principios del siglo XVII, RuIZ IBÁÑEZ, J. J.: op. cit., 1995, pp. 243-262. 
das por la los vecinos en armas que se hallaban dispersas por las distintas poblaciones del reino: las compañías parroquiales, cuya función de defensoras del orden comunitario había derivado en una fuerza movilizable por el monarca en coyunturas extraordinarias ${ }^{42}$. Entre estas compañías ciudadanas destacaban por su número y operatividad las procedentes de la capital, la cual llegó a enviar a Cartagena durante el peligro de la armada francesa en el verano de 1693 tres socorros consecutivos de más de 500 hombres cada uno, lo que suponía militarizar durante un periodo prolongado alrededor de un $10 \%$ de los vecinos útiles de la ciudad ${ }^{43}$.

En las ocasiones en las que estas fuerzas resultaban insuficientes surgieron nuevas compañías levantadas por destacados oligarcas locales que, haciendo efectiva su capacidad de convocatoria a través de lazos clientelares, invirtieron su capital social en busca de una merced: ese fue el caso de la compañía de 150 hombres levantada por don Alonso Hernández Reillo, regidor de Cartagena, en el socorro a esta ciudad de 1691; o el de los doscientos hombres agrupados en tres compañías que los regidores lorquinos don Alonso de Guevara, don Pedro de Tudela y don Diego de Alburquerque enviaron tres años antes a la defensa de Orán; la prestación personal de estos capitanes sería recompensada posteriormente con el esperado hábito de orden militar ${ }^{44}$. Esta apropiación de la coerción que ejercían las elites locales sobre la población, reflejaba la estrecha relación existente entre estos poderes y la Corona; y además de constituir para el monarca un servicio de especial interés en momentos en los que la rapidez de la intervención resultaba el factor prioritario, también representaba para el vasallo un medio eficaz con el que lograr incrementar el propio capital simbólico.

En algunos momentos, esta labor defensiva que desarrollaban las milicias del reino traspasó los límites que aún dividían los reinos peninsulares. Ese fue

${ }^{42}$ Un informe del estado de todas ellas y las posibilidades de restauración en AGS GA 2718, sn: Murcia, 3-VI-1686: don Antonio Colmenero (sargento mayor de milicias del reino) a don Juan Antonio López de Zárate. Para el caso similar de Flandes, RuIz IBÁÑEZ, J. J.; Felipe II y Cambrai: el consenso del pueblo. La soberanía entre la práctica y la teoría politica (1595-1677), Madrid, 1999, pp. 38-42.

43 AMM AC 1693 AE 14-VII-1693: primer socorro de 550 hombres; AC 1693 AE 1 y 2VIII-1693: segundo de 510; y AC 1693 AE 15-X-1693: tercero de 500.

44 El socorro de los regidores lorquinos también se componía de 200 fanegas de trigo, lo cual «dice lo mucho que merecen la prontitud y el ejemplo de esta ciudad y estos tres capitulares para que Su Majestad los honre como lo espero de su magnificencia, considerando también que ninguna de estas tres compañías es de milicias con que se hace más voluntaria la acción», AGS GA 2789, sn: Cartagena, 13-IX-1688: don Antonio de Heredia Bazán (gobernador) a don Juan Antonio López de Zárate. Respecto a don Alonso Hernández Reillo, «el primero» en acudir al socorro de Cartagena de 1691, además de prestar trigo para Orán y Cataluña, escribía el gọbernador de Cartagena que era «hombre muy acomodado que pretende que su Majestad le honre con una merced de hábito de las Ordenes militares que recaerá muy bien en persona de su calidad y servirá para alentar a otros [el subrayado es nuestro]", 2882, sn: Cartagena, 6-VIII-1691: los mismos; dos años más tarde efectivamente acontecería lo mismo con el también regidor de Cartagena don Simón García Angosto, 2942, sn: Cartagena, 11-VIII-1693: los mismos.

Hispania, LXIII/3, núm. 215 (2003) 969-994 
el caso del auxilio de hombres armados que las ciudades - Chinchilla y Villena- y villas - Yecla, Almansa, Albacete, La Roda - del marquesado de Villena y la zona manchega del reino de Murcia realizaron a la relativamente cercana ciudad de Alicante durante el bombardeo francés de 1691. La marcha de más cien hombres, junto a su «nobleza» en pleno, representó, más allá de la oportunidad de invertir en un servicio remunerable, otra nueva alteración en la naturaleza de estas fuerzas ciudadanas y una buena muestra del grado de movilización social que la Corona lograba en los momentos de mayor agresión exterior. Este socorro de 1691 no se convirtió en una excepción, y dos años más tarde el gobernador de Alicante, don José de Borja Lanzor, hacía otro llamamiento de auxilio que incluía hasta la propia ciudad de Murcia, ocupada entonces en las operaciones simultáneas de defensa de la plaza de Cartagena ${ }^{45}$.

- Menor grado de respuesta surgía entre los naturales del reino de Murcia con las solicitudes de la Corona para acudir a la defensa de Orán, plaza estrechamente unida al territorio murciano en avituallamiento y refuerzos militares. A su lejanía, a su acentuado carácter de zona caliente de la Monarquía y a las negativas experiencias que hacía poco habían sufrido los propios vecinos de la capital del Segura ${ }^{46}$, se sumaba la ausencia real de obligatoriedad en ese servicio, respondiendo su contribución en hombres y en trigo a un rasgo más de «voluntariedad» o a la vaga "obligación general de vasallo» que de responsabilidad legítima de los habitantes de este reino castellano ${ }^{47}$. Era en ese instante cuando se activaba el recurso a los lazos de dependencia entre las diversas facies del sistema monárquico y sus receptores locales, a su vez encargados de producir un discurso primario de conservación de la Monarquía sustentado en una tradición comunitaria de servicio al soberano ${ }^{48}$. A esta informal articulación política respondería la movilización de determinados intereses particulares ${ }^{49} \mathrm{y}$,

45 AGS CJH 1578, sn: Albacete, 7-IX-1691: don Fernando Alcañabate de la Cueba (alcalde mayor) al Consejo; y 1643, sn: Madrid, 29-II-1692: certificación del escribano don Francisco Jiménez de Arroyo; sobre la carta enviada a Murcia, AMM AC 1693 AE 5-VIII-1693.

46 En 1676 las dos compañías de milicias pasaron al socorro de Orán permaneciendo allí tres años, lo que se tradujo en numerosas pérdidas de vidas y en el empobrecimiento de muchas familias, AGS GA 2371, sn: Murcia, 14-III-1676: el corregidor don Juan Henao Mongaraz, y sobre su actualización años después, AMM AC 1687 AO 15-VII-1687 y AE 20-VII-1687.

47 AGS GA 2781, sn: Murcia, 4-V-1688: la ciudad a don Juan Antonio López de Zárate, donde también se solicita la contribución del resto de ciudades y villas del reino; a igual conclusión llegaba el gobernador de Cartagena años más tarde, 2908, sn: Cartagena, 14-IV-1692: el gobernador al mismo.

48 «[...] para que esta ciudad continuando su celo y lealtad en el Real Servicio en esta ocasión como en todas lo ha ejecutado, se halle con la noticia de lo referido y obre según lo promete la experiencia de los casos antecedentes y según su gran fidelidad y nobleza se lo participa [....]», AMM AC 1687 AO 12-VII-1687; argumento parecido lo esgrimió la ciudad de Lorca para el mismo socorro a Orán, AML AC 1687 AO 2-VIII-1687.

49 Sumemos a otros ejemplos anteriores, el de la compañía de caballos de Yecla, AGS GA 2781, sn: Yecla, 2-V-1688: el capitán don Pedro González del Valle y Miranda a don Juan Antonio 
muy especialmente, las intervenciones de los más relevantes patrones en la Corte; algunos situados coyunturalmente por razón de los empleos cortesanos alcanzados, caso del lorquino don Ginés Pérez de Meca, presidente del Consejo de Hacienda entre 1687 y $1691^{50}$; mientras que en otros, como el VI marqués de los Vélez, don Fernando Joaquín Fajardo, las causas respondían a una naturaleza mixta: a su cargo patrimonial de adelantado y capitán mayor, se añadía su amplia carrera cortesana, lo que le convertía en el principal factor de mercedes para las élites locales ${ }^{51}$. Las apelaciones de estos agentes monárquicos con probado ascendiente sobre el territorio terminaron por hacer propia, en muchas ocasiones, una suplementaria contribución, tanto personal como en recursos materiales.

Los requerimientos para la defensa de otras fronteras alejadas de la Monarquía también se tradujeron en parecidas consecuencias fiscales sobre gran parte de los veinticinco mil vecinos que vivían en el reino de Murcia ${ }^{52}$. Tanto las tropas levantadas con destino a refuerzos de los frentes catalán y flamenco durante la Guerra de los Nueve años, como el reclutamiento efectuado para otras zonas del Mediterráneo, especialmente los tres virreinatos italianos, el Estado de Milán o la plaza de Orán, particularizaron la asistencia de este territorio concreto a un programa común de conservación de la Monarquía ${ }^{53}$.

Los sucesivos fracasos en la contención de las tropas de Luis XIV durante 1692 y 1693 conllevaron un aumento de la demanda de efectivos en el conjunto de la Corona de Castilla ${ }^{54}$. En Murcia esta suplementaria petición se tradujo en la imposición de un servicio personal extraordinario en un momento de falta de liquidez de la hacienda municipal. Precisamente debido a esta causa, y en pleno proceso negociador entre la ciudad y la Corona, alguno de sus capitulares

López de Zárate; Murcia, 23-V-1688: los mismos: sobre el socorro de 12.000 Rs; Cartagena, 14VI-1688: el gobernador al mismo: sobre el embarque para Orán de la compañía yeclana.

so Por ejemplo, AML AC 1687 AO 2-VIII-1687: carta de don Ginés Pérez de Meca a su hermano don Antonio, regidor, «insinuado a esta ciudad en el estado en el que se hallan las Plazas de Orán y Mazarquivir faltos de mantenimientos para su conservación y defensa contra las invasiones del turco».

${ }^{51}$ JIMÉNEZ ALCÁZAR, J. F.: «Los parientes e amigos de los unos e de los otros: los grupos de poder local en el reino de Murcia (ss. XIII-XVII)», en Anales de la Universidad de Alicante. Historia Medieval (Alicante), 13 (2001) pp. 243-295. Este patronazgo centro-periferia guarda ciertas similitudes con el modelo francés de Kettering, S.; Patrons, Brokers, and Clients in Seventeenth Century France, NewYork Oxford, 1986, pp. 157-165, y «Friendship and Clientage in Early Modern France» en French History (Oxford) 6-2 (1992) pp. 139-158.

52 AGS GA 2934: Relaciones del vecindario de la Corona de Castilla para el servicio militar del mismo año 1693.

53 El ejemplo del ejército milanés en STORRS, Ch.: «The Army of Lombardy and the Resilience of Spanish Power in Italy in the Reign of Carlos II (1665-1700). Part I \& II» en War in History (Londres) 4-4 (1997) pp. 371-397 y 5-1 (1998) pp. 1-22, respectivamente.

54 ESPINO LÓPEZ, A.: Catalunya durante el reinado de Carlos II. Política y guerra en la frontera catalana, 1679-1697, Barcelona, 1999, esp. cap. 2. 
intentó romper el déficit de títulos nobiliarios del ayuntamiento — sólo dos los habían adquirido recientemente- a cambio de sufragar los gastos de la urgencia reals5. Esa fue la estrategia que subyacía en la propuesta de don Pedro Fontes Carrillo, desactivada inmediatamente por otros regidores, asimismo insertos en proyectos de titulación. La apelación al papel que jugaba Cataluña como «antemural» físico de los reinos de Aragón y Castilla y, sobre todo, la capacidad de influencia que demostraron, por un lado, el corregidor de Murcia y, por otro, un reciente representante de la Corona, el gobernador de lo político y militar de Cartagena, despejaron cualquier vacilación de la ciudad para la consecución de esta nueva exacción: la capital del reino levantaría a su costa dos compañías de infantería como contribución a los tercios provinciales para las campañas de 1691 y 1693 . La consecuencia inmediata para la población consistió en un aumento de la presión fiscal - vía arbitrios y endeudamientodurante los siguientes años ${ }^{56}$.

Pero el agravamiento de los frentes de batalla de Cataluña y Flandes iba a ocasionar otra consecuencia de mayor calado, ya que terminaría por agotar los sistemas mayoritarios de reclutamiento. La movilización de hombres procedía hasta ese instante básicamente de compañías levantadas por conducta o comisión y a partir de asientos acordados con sus capitanes: desde 1685 a 1698 se presentaron únicamente en la ciudad de Murcia 38 oficiales para enrolar gente mediante ambos sistemas ${ }^{57}$. Sin embargo, el retroceso en las posiciones catalanas influyó para que la Corona impusiese métodos más coercitivos con los que procurar mayor resistencia en la frontera catalana. Por esta razón, a partir de 1694 se volvió a introducir el sorteo de vecinos como instrumento de recluta, transformando lo que en las últimas décadas había sido una participación militar de carácter voluntario en una nueva contribución obligatoria, al igual que había sucedido en la difícil década de $1630^{58}$.

Este incremento sensible de la carga fiscal sería administrado por los concejos, a los que se le otorgaban la capacidad decisoria en la confección de las listas y en la realización de los sorteos ${ }^{59}$, aunque bajo la supervisión última de los

\footnotetext{
55 AMM AC 1690 AE 20-II-1690: memorial de don Pedro Fontes Carrillo.

56 El reclutamiento de estas compañías puede seguirse en AMM AC 1690 AAEE 11, 12, 18III y 11-IV-1690, y para la leva posterior, AC 1692 AE 26-II y AAOO 28-II, 3, 4, 10-III, y 14 y 28-IV-1693; AGS GA 2853, sn: 14-III-1690: el corregidor al marqués de Villanueva, y 2854, sn: Murcia, la ciudad al mismo, sobre la compañía para Cataluña; y 2850, sn: Cartagena, 1-V-1690: el duque de Veraguas, almirante de las Galeras de España, sobre la embarcación de la compañía; el embarque de la renovación de esta compañía (50 hombres), GA 2939, sn: Cartagena, 4-V-1693: el gobernador al marqués de Villanueva.

57 MUÑOz RodríGUeZ, J. D.: op. cit., pp. 174-181.

${ }^{58}$ RuIZ IBÁÑ̃Z, J. J.; op. cit., 1995, pp. 329-331.

59 "[...] no han de tener menos de veinte años ni pasar de cincuenta, que no sean casados», añadiendo el concejo a aquellos que fuesen hijos únicos, AMM AC 1694 AAEE 1 y 6-II-1694; en posteriores sorteos se mantendrían estas condiciones.
} 
corregidores $^{60}$. Las frecuentes arbitrariedades que se dieron para alcanzar el correspondiente número total de hombres hábiles sirvieron para que se generalizaran las apelaciones a cualquier suerte de privilegio estamental - hidalguía ${ }^{61}$ personal -matrimonio ${ }^{62}$ - o corporativo - amparo eclesiástico ${ }^{63}$ - con el fin de evitar la posibilidad de verse trasladado a un frente de batalla. Fallados estos medios, sólo quedó para bastantes vecinos la opción extrema de pasar a ser fugitivos de la ley e integrarse, frecuentemente, en partidas de bandoleros ${ }^{64}$. De esta manera, en la ciudad de Murcia, por ejemplo, sobre una población algo superior a los cinco mil vecinos, se reclutaron en cuatro años 291 hombres por este sistema, distribuidos en el $2 \%$ (dos soldados de cada cien vecinos) de $1694,1 \%$ de 1695 , y sendos $1,3 \%$ (un soldado de cada setenta y cinco) en 1696 y 1697, año en que se firmó la paz con Francia por el Tratado de Ryswick. La cuantía final de quintos venía a evidenciar, más que la contrastada efectividad del reclutamiento obligatorio, la correlación de intereses de las oligarquías locales con la Corona y la coacción ejercida sobre la población por los diferentes delegados regios; los primeros capitanes de las compañías formadas por este sistema en 1694 serían don Francisco Molina de Junterón y Almela y don Baltasar Fontes de Albornoz, ambos miembros de sendos linajes de dilatada tradición municipal ${ }^{65}$.

\section{HACIA UNA VÍA EJECUTIVA EN LA FISCALIDAD...}

El modelo hacendístico sobre el que se sustentaba la Monarquía respondía a una gestión básicamente descentralizada, que se reflejaba, al menos formal-

60 AMM AC 1694 AE 1-II-1694: real carta (Madrid, 20-I-1694); AC 1695 AE 3-I-1695: real carta (Madrid, 13-XII-1695), el corregidor citaría a cabildo a todos los regidores so pena de dos ducados «aplicados de por mitad real cámara de Su Majestad y gastos de Justicia»; AC 1696 AO 7-I-1696: real carta (Madrid, 22-XII-1696); y AC 1697 AE 18-I-1697: real carta (Madrid, 4-I-1697).

61 AMM AC 1696 AO 18-II-1696: exención de los hidalgos en las listas parroquiales por lo «desacostumbrado» de su contribución.

62 «[...] se han casado los más de los mozos que había para relevarse, de tal forma que hoy quedan muy pocos y estos no de la edad suficiente y todos bien ocupados en el servicio de sus padres a quienes harán mucha falta si se echare mano de ellos por ser los más muy viejos y algunos que no tienen padre, sino madre y hermanas a quien sustentan con su trabajo", AML AC 1696 AO 14-I1696. En la real carta de 1695 se advertía que se procediese a la ejecución del sorteo «excusando en cuanto sea posible imaginable las molestias con que en otras ocasiones por malicia de los ejecutores se hizo casi intolerable a los pueblos esta disposición", AMM AC 1695 AE 3-I-1695: real carta (Madrid, 13-XII-1695).

${ }^{63}$ El corregidor de Lorca, don Francisco Calderón, admitiría que «todos los sujetos que la ciudad tiene nombrados y nombró el año pasado se hallan ausentes fugitivos y algunos de ellos en las iglesias, donde no se pueden prender», AML AC 1695 AO 1-II-1695.

${ }^{64}$ Noticias de estas partidas de «gentes licenciosas», por ejemplo, en AMM AC 1691 AE $12-$ VI-1691, y AC 1692 AE 13-VI-1692.

65 AMM 2484, sn: Murcia, 25-VIII-1694: «Autos para la recluta de dos compañías de infantería española que se han de hacer en esta ciudad a costa de la Real Hacienda». 
mente, en la delegación de competencias defensivas o recaudatorias que la Corona había realizado en instituciones locales y provinciales ${ }^{66}$. En este sentido, gran parte de los cargos pertenecientes a la estructura administrativa de las rentas reales no había quedado al margen de la venalidad de oficios, si bien en un grado mucho menor al que habían sido objeto los regimientos castellanos. Por ejemplo, y sólo dentro del ámbito provincial murciano, la Corona había enajenado dos escribanías de Millones: una — denominada «mayor»- que ejercía don Juan de Valcárcel y Dato ${ }^{67}$, y otra que incluso poseía vinculada el regidor cartagenero don Antonio Fadrique Fernández de Santo Domingo, cliente del marqués de los Vélez ${ }^{68}$; en esta misma situación se encontraba el alguacilazgo mayor de Millones, oficio que había sido perpetuado por el regidor de Murcia don Alonso Bernal, quien lo ejercía mediante teniente ${ }^{69}$; también desempeñados por terceros se encontraban el alguacilazgo mayor de alcabalas y una de sus escribanías, ambas propiedad de don Alonso de Frías ${ }^{70}$. El estado en que se presentaban los instrumentos receptores de la Hacienda real coincidía, además, con otro factor general desde la década 1670: el debilitamiento del apoyo crediticio exterior, que reducía a los recursos propios de la Monarquía el mantenimiento de su todavía extensa estructura imperial ${ }^{71}$.

La coyuntura económica favorable desde 1680 , junto a las pautas consensuales en las que estaban basadas la relación entre la Corona y las elites provinciales, favorecieron los proyectos de optimización del fisco castellano. Ese fue uno de los objetivos de la Junta de Encabezamientos, puesta en marcha en 1682 por el duque de Medinaceli, la cual desarrolló la figura del superintendente de

${ }^{66}$ RUIZ IBÁÑEZ, J. J.: op. cit., 1995, pp. 292-295; ANDRÉs UCENDO, J. I.: op. cit., 1999, pp. 43-55; y MACKAY, R.: The Limits of Royal Authority. Resistance and Obedience in Seventeenth-Century Castile, Cambridge, 1999.

${ }^{67}$ AGS CJH 1531, sn: Murcia, 22-IV-1687: don Francisco Manuel (corregidor y superintendente) al Consejo.

${ }^{68}$ AGS CJH 1531, sn: Murcia, 13-VII-1688: don Lucas Yáñez de Barnuevo (corregidor y superintendente) al Consejo, donde se inserta copia del título. Además era visitador de las torres de la costa del reino, nombramiento que correspondía directamente al marqués de los Vélez y que posteriormente ocuparía su yerno don Pedro García Garre de Cáceres, ACMS 1294, sn: s/f, pero hacia 1730: don Francisco López Oliver a Francisco Javier González de Rivera.

69 AHPM protocolo 2174 escribano Juan de Valcárcel y Dato, 21-X-1677: nombramiento de Antonio Francisco Conde; este oficio pasaría después a don Antonio Grafión Arias Monreal, juez conservador de las fábricas reales de pólvora y salitres de la ciudad y reino de Murcia.

70 AGS CJH 1538, sn: Murcia, 6-IV-1688: don Lucas Yáñez de Barnuevo al Consejo; la alguacilazgo lo ejercía don Nicolás de Alba y la escribanía don Pedro Ruiz Abarca. En esta misma situación se hallaba el oficio de contador de las Rentas reales de San Clemente y del partido del marquesado de Villena que había sido comprado por mil ducados, 1546, sn: don Pedro de los Herreros al Consejo.

71 Herrero Sánchez, M.: op. cit., 2001, pp. 45-60, Álvarez Nogal, C.: El crédito de la Monarquía Hispánica en el Reinado de Felipe IV, Ávila, 1997; SANZ AYÁN, C.: «Negociadores y capitales holandeses en los sistemas de abastecimientos de pertrechos de la Monarquía Hispánica durante el siglo XVII» en Hispania (Madrid), 182 (1992) pp. 915-945.

Hispania, LXIII/3, núm. 215 (2003) 969-994 
rentas reales y millones en cada provincia. Éste, a su vez, centralizaría las funciones ejecutivas en un nuevo cargo común para toda Castilla surgido bajo cierta inspiración colbertista, como era en concreto el controleur général des finances ${ }^{72}$; este superintendente general, puesto que ocuparía durante la década de 1680 el VI marqués de los Vélez, constituiría el más directo antecedente de lo que posteriormente sería el secretario de Estado de Hacienda borbónico ${ }^{73}$.

Aunque la reforma de Medinaceli no introducía una innovación institucional extraordinaria, por cuanto ya venía funcionando el esquema organizativo de las superintendencias de rentas desde la década de 1650, sí le confirió mayor margen de acción (al presentarse como apéndice del superintendente general) y lo consolidó entre la confusión de jueces ejecutores y administradores que aparecían dentro de los engranajes periféricos de la Hacienda real ${ }^{74}$. Este agente del poder regio en los territorios castellanos pasó a ser la figura especializada de todo lo concerniente a la recaudación, administración e inspección de los derechos hacendísticos procedentes de las ciudades y villas, el pago de salarios de los oficiales reales, además de superponerse a una serie de puestos subalternos: desde escribanos y contadores a arqueros, fieles ejecutores, alguaciles y demás ministros ${ }^{75}$. Su poder relativo conllevaba necesariamente una merma del que había sido privativo tanto de corregidores, como de los principales concejos

72 RicheT, D.: La Francia Moderna. El espíritu de las instituciones, Madrid, 1997 [1 ${ }^{\mathrm{a}}$ ed. París, 1973] pp. 92-96.

73 «[...] lo que conviene que todas las dependencias de Hacienda corran por una mano para que unidas se faciliten las provisiones generales», AHN E 6001, cit. en BERMEJO CABRERO, J. L.: «Superintendencias en la hacienda del Antiguo Régimen» en Anuario de Historia del Derecho Español (Madrid) 54 (1984) pp. 409-447, p. 431; igualmente, SÁnCHez BeléN, J. A.: op. cit., 1996, pp. 37-50, y especialmente su «Absolutismo y fiscalidad en Castilla a fines del siglo XVII: el encabezamiento general del reino (1682-1685)» en Espacio, Tiempo y Forma, Serie IV (Madrid) 2 (1989) pp. 175-218. Paralelamente en Portugal iría asumiendo mayores competencias del ámbito hacendístico el "secretario de Estado", al respecto CARDIM, P.: «Política cortesana y administración en Portugal en la segunda mitad del siglo XVII» en GuILLAmón ÁlvareZ, F. J: et alii: Entre Clío y Casandra. Seminario Extraordinario Floridablanca (Murcia, 7 y 8 de noviembre de 2002) en prensa.

${ }^{74}$ RuIZ IBÁÑEZ, J. J.: op. cit. en Le forze del principe... (en prensa); MONTOJO MONTOJO, V.: «La intendencia de Provincia de Murcia y sus contadurías: institución y documentación fiscal en Murcia (1749-1849)» en Murgetana (Murcia) XCIV (1997) pp. 89-106, y ROSA FERRER, I. de la: «La superintendencia general de las Rentas Reales del Marquesado de Villena en el siglo XVII. Análisis institucional» en La investigación y las fuentes documentales de los archivos, Guadalajara (1996) pp. 685-709.

75 Un listado de estos con sus salarios para el caso de la ciudad de Murcia y Cartagena en AGS CJH 1531, sn: Murcia, 22-IV-1687: don Francisco Manuel al Consejo, y Murcia, 16-III-1688: don Lucas Yáñez de Barnuevo al Consejo; en esa última ciudad se situaba un administrador de Millones, don Miguel de Montenegro, subordinado al superintendente. La valoración del papel de estos cargos secundarios, y en concreto del arquero, en DEDIEU, J. P.: «El arca de rentas reales de Villanueva de los Infantes a finales del siglo XVII. La cuenta de Tomás Marco Ortega (1685-1690)» en Cuadernos de Historia Moderna (Madrid) 21 (1998) pp. 103-125, y RUIZ RODRíGUEZ, J. I.: «Estructura y recaudación del Servicio de Millones (1590-1691)» en Hispania (Madrid) 182 (1992) pp. 1073-1088.

Hispania, LXIII/3, núm. 215 (2003) 969-994 
castellanos. No ha de extrañar que estas instancias políticas fueran las más enérgicas opositoras a su tarea de actualización y control tributario. En este ambiente de resistencia se originaban acusaciones como las que en 1687 hicieron los regidores murcianos contra el superintendente, don Francisco López Camacho, sobre que «viene extralimitándose en sus funciones» frente a los escribanos del Concejo «con la aquiescencia del antiguo corregidor»; o, asimismo, peticiones como las que formuló el corregidor don Antonio de Funes solicitando que «acomodara cuanto antes en cualquier cosa al conde de Belmonte [superintendente] en que no le hará Vuestra Ilustrísima pequeño favor y a mi muy grande merced», porque, alegaba el corregidor, «el gasto que tengo para mantener lo respetuoso de este empleo no le puede sobre llevar mis cortos medios y no siendo Murcia capaz de tener superintendente y corregidor ${ }^{76}$.

Quizás en la persecución del fraude a la Hacienda real fuese donde más conflictos suscitó este delegado de la Corona. La existencia de un extenso litoral poco poblado en el caso murciano, y la tolerancia de la Corona hacia una fenómeno que no era entendido en último término como quebranto de su autoridad $^{77}$, facilitaron el mantenimiento y expansión del contrabando especialmente de grano. Los sucesivos superintendentes intentaron poner freno a estas desviaciones que frecuentemente eran protagonizadas por poderosas instancias locales - como el cabildo catedralicio ${ }^{78}$ - o los mismos oficiales reales ${ }^{79}$, a través, incluso, de la denuncia judicial en instancias y tribunales superiores. En tales casos, el superintendente debilitaba su posición entre los pilares del poder local, lo que contribuyó finalmente a que la Corona traspasase en algunos periodos su título y competencias a los mismos corregidores ${ }^{80}$.

Mejores resultados se consiguieron, sin embargo, en la fijación de las cantidades adeudadas a la Hacienda real por los diversos cabildos municipales. Aunque fue moneda corriente la supresión de parte de éstas en forma de gracia

${ }^{76}$ AMM AC 1687, AO 19-VII-1687; y AHN CS 13619, n 47: Murcia, 16-II-1694: el corregidor al Consejo de la Cámara; también, SÁNCHĖz BelÉN, J. A.: op. cit., 1989, pp. 186-194.

77 CÁRCELES DE GEA, B.: Fraude y desobediencia fiscal en la Corona de Castilla, 1621-1700, Valladolid, 2000, pp. 53 y 54 .

${ }_{78}$ Los prebendados murcianos sacaron tres mil fanegas de trigo y cebada en la saetía del patrón Rafael Golba empleando el recurso de la excomunión ante el alcalde mayor de Cartagena, a pesar de recibir órdenes contrarias del gobernador; éste le multaría para que «sea más atendido a mi puesto", AGS GA 3039, sn: Cartagena, 17-IX-1696: el gobernador al marqués del Solar (presidente del Consejo); Cartagena, 23-IX-1696: los mismos; y Cartagena, 1-X-1696: los mismos, estas dos últimas cartas con autos.

79 Don Sebastián de Figueroa, gobernador de Cartagena, amparaba que un criado suyo, Pascual Sánchez, vendiese carne, AGS CJH 1495, sn: Madrid, 23-XI-1685: acuerdo de la sala de Millones; el alcaide de la torre de la Azohía, Pedro García, hacía contrabando de barrilla, 1550, sn: Murcia, 1-XI-1689: el corregidor y superintendente Yáñez de Barnuevo al Consejo; o el duque de Nájera, general de las Galeras, mantenía «despensa pública» en su misma casa de Cartagena, 1666, sn: Madrid, 7-IX-1697: acuerdo de la sala de Millones (inserta autos hechos por la ciudad)

80 SÁNCHEZ BELÉN, J. A.: op. cit., 1989, esp. pp. 208-210. 
real con el fin de facilitar la normalización de la presión fiscal ${ }^{81}$, las sumas a deber por las ciudades y villas murcianas descendieron en 1697 entorno un $85 \%$ respecto a las alcanzadas a mediados de siglo ${ }^{82}$. Parte del logro de este descenso debe ser atribuido a superintendentes y administradores que rebajaron las cantidades adeudadas, con la condición de pagar el resto del pasivo o a cambio de algunas cantidades de trigo y cebada para el ejército ${ }^{83}$. Si bien estos métodos potenciaban los resortes de negociación entre Corona y poderes locales, también fueron acompañados de procedimientos más coercitivos como el despacho de comisiones y jueces extraordinarios ${ }^{84}$. De ahí, que esta labor de actualización fiscal requiriese una legitimación añadida, además de una completa formación burocrática de la que habían carecido los corregidores tradicionales de capa y espada, con la que intentar anteponer «el servicio de Vuestra Majestad y el alivio de los vasallos a sus conveniencias» ${ }^{85}$.

Probablemente, el reducido empleo de nuevos impuestos para elevar la carga fiscal durante el reinado de Carlos II $^{86}$, fuese debido a la mayor entrada de liquidez conseguida por otras vías: tanto las procedentes de la enajenación del patrimonio regio y la mercantilización de la gracia real ${ }^{87}$, como también a los elementos de eficacia implantados por estos delegados regios. Lo que no ofrece muchas dudas es que a los castellanos que aún vivieron en las primeras décadas del siglo

81 CÁRCELES DE GEA, B.: op. cit., 1995, pp. 101-107.

82 Para la cantidad adeudada entre 1642 y 1658 (351.635.000 mrs), en THOMPSON, I. A. A.: op. cit., 1998, pp. 287 y 288; un listado por localidades en 1697 en AGS CJH 1672, sn: Murcia, 14-I-1697: don Francisco de Ceballos (corregidor y superintendente) al Consejo.

${ }^{83}$ Ese fue el caso de la ciudad de Villena que propuso pagar sus débitos del servicio ordinario y extraordinario y el chapín de la reina mediante su equivalencia en estos dos cereales, aunque las malas cosechas del año posterior terminaría por aplazar las entregas, AGS CJH 1651, sn: Villena, 28-XII1695: la ciudad al Consejo; Murcia, sn: 31-I-1696: el conde de Belmonte (superintendente) al mismo; Murcia, sn: 14-II-1696: los mismos; 1669, sn: Madrid, 26-VI-1698: la ciudad al Consejo:

${ }^{84}$ Esta función del superintendente la hemos desarrollado en "Cuando el rey se hace presente. El superintendente como elemento racionalizador en la recaudación fiscal castellana (1682-1700)», comunicación presentada a la VII Reunión Científica de la Fundación de Historia Moderna, Ciudad Real (3-6 de junio de 2002), en prensa.

85 AGS CJH 1552, sn: Madrid, 6-XII-1689: consulta del Consejo, en la que se informa de lo cobrado por el corregidor y superintendente don Lucas Francisco Yáñez de Barnuevo en los dos últimos años ( $57.518 .981 \mathrm{mrs}$ ) que ha estado a su cargo esta superintendencia, y se solicita que se le otorgue un salario (500 ducados cada año) por estos progresos administrativos debidos a «su grande inteligencia y aplicación como por el sumo interés con que ha tratado esta materia».

${ }^{86} \mathrm{El}$ nuevo impuesto de la sal supuso en la práctica un atentado contra «los privilegios del Reino», que fue sólo tolerado por el carácter explícito de «urgencia» que se pedía; AMM CR (16901697), sn: Madrid, 6-IV-1695: Real carta aumentando 4 reales en cada fanega de sal, y AC 1695 AAOO 24-IV-1695: despachos, y 26-IV-1695: votación; para la ejecución del superintendente, AGS CJH 1643, sn: Murcia, 26-IV-1695: el conde de Belmonte a don Ignacio Bautista de Rivas.

${ }_{87}$ ThOmpSON, I. A. A.: «The Purchase of Nobility in Castile, 1552-1700» en War and Society in Habsburg Spain. Aldershot, 1992, pp. 313-360; SANZ AYÁN, C.: op. cit., 1988, pp. 451-464; y SÁNCHEZ BELÉN, J. A.: op. cit., 1996, p. 307. 
XVIII —años trágicos, además - no les representaría una subrayable novedad la creación de los intendentes borbónicos, puesto que su implantación respondía notablemente a un propósito optimizador de recursos - centralizador en sus consecuencias institucionales- asumido indirectamente con anterioridad ${ }^{88}$.

\section{... PERO TAMBIÉN EN LA ORGANIZACIÓN DE LA DEFENSA}

Este proceso de jerarquización practicado en los medios de recaudación fiscal de la Monarquía hispánica tuvo asimismo su correspondencia en el área defensiva. La multiplicidad de agentes encargados en la organización de una respuesta local a la agresiones enemigas, requirió de impulsos racionalizadores en la coerción a la que estaba sometida la población. Las medidas de simplificación de antiguas jurisdicciones ciertamente perseguían la consecución de una mayor efectividad de los medios disponibles, pero, implícitamente, también originaron una centralización de la información sobre la que concretar decisiones de forma más rápida; la colaboración entre Corona y poderes locales que caracterizó esta coyuntura, facilitó la asunción de estos incipientes cambios en los «estilos» tradicionales de gestión política.

Si bien el reino de Murcia contaba con el cargo patrimonial de origen bajomedieval de adelantado y capitán mayor, las necesidades defensivas de esta parte de la Monarquía requerían de una atención personal que distaba de poder ofrecer el marqués de los Vélez; su habitual alejamiento de territorio murciano, especialmente durante la segunda mitad del siglo XVII por el desempeño de cargos burocráticos - virreinatos-y cortesanos - consejos-, impulsaron el carácter aristocrático que la casa Fajardo fue adquiriendo desde el siglo XVI ${ }^{89}$. El corregidor de Murcia, que también lo era de Cartagena, poseía su residencia en la capital y, aunque disponía de un alcalde mayor en la ciudad portuaria, no reunía la formación técnica apropiada que demandaba una base militar del Mediterráneo ${ }^{90}$. Co-

\footnotetext{
${ }^{88}$ Los intendentes borbónicos han sido tratados, entre otros, por KAMEN, H.: «El establecimiento de los intendentes en la administración española» en Hispania (Madrid) XXIV (1964) pp. 368-395; Fernández Albaladejo, P.: op. cit., 1992, pp. 372-380; y OZANAM, D.: «Les intendants espagnols de la première moitié du XVIII siècle, 1711-1749» en DescimON, R. SCHAUB, J. F. y VINCENT, B. (Dirs.): op. cit., 1997, pp. 181-199.

89 Un buen ejemplo es la obra de don Bonaventura TONDI DA GubBio OliveTANO, Gli Eroi Fassardi, Nápoles, 1682, obra de la que hay en curso un extenso trabajo en el que participamos; sobre esto mismo, YUN CASAlilla, B.: «La aristocracia castellana en el Seiscientos: ¿Crisis, refeudalización u ofensiva política» en La gestión del poder. Corona y economías aristocráticas en Castilla (siglos XVI-XVIII), Madrid, 2002, pp. 197-219.

${ }^{90} \mathrm{La}$ formación mayoritaria de los corregidores del último tercio correspondía a la jurídica, desarrollada en la Chancillería de Granada, caso de los oidores don Francisco Ceballos Escobedo y Velasco (AMM CR 1690-1697 Madrid, 18-III-1696: nombramiento real) o don Pedro de Larreátegui y Colón (CR 1690-1697 Madrid, 21-XII-1697), o la meramente burocrática originada desde el servicio producido en los concejos de voto: procedentes de Córdoba eran don Francisco Manuel de Lando, caballero de
} 
mo consecuencia de la falta de disponibilidad de estos dos cargos, y con ciertas semejanzas a lo que la Corona había dispuesto para otros puertos mediterráneos (Cádiz, Málaga, Vera-Almería, Alicante), surgiría hacia 1651 la plaza de gobernador de lo político y militar de Cartagena ${ }^{91}$.

Este nuevo delegado del rey fue ejercido, salvo alguna interinidad, por oficiales de amplia experiencia: el primero de ellos fue el general de artillería don Gonzalo Fajardo Manrique y Mendoza, conde de Castro y mayordomo del rey, que lo ostentó durante la minoría de edad de su sobrino, el VI marqués de los Vélez, con primacía sobre el resto de corregidores del reino92. Más tarde, se sucederían el conde don Carlos Antonio Colonna (1662-1671)93, el general de artillería y caballero de la orden de Alcántara don Juan González Salamanqués (1672-1676)94 el también general de Artillería don Francisco de Angulo y Castro (1677-1681)95, y don José de Frías (1681-1684)96, don Sebastián de Figueroa (1684-1687)97 y don Antonio Heredia Bazán (1687-1703)98, estos tres últimos, además, con el grado de sargentos mayores de batalla. Desde

Alcántara (CR 1683-1688 Madrid, 21-IV-1684) y don Fernando de Cea y Córdoba, caballero de Calatrava y gentil hombre (CR 1690-1697 Madrid, 13-XI-1690); de Soria procedía don Lucas Yañez de Barnuevo y Santa Cruz, caballero de Alcántara (CR 1683-1688 Madrid, 23-VI-1687).

${ }_{91}$ Sobre esta red nuestra comunicación «El gobernador de lo político y militar: Aparición y consolidación de una nueva figura administrativa en la defensa de las costas del Mediterráneo meridional (ss. XVII-XVIII)» en Actas del Tercer Congreso de Historia de Andalucía, Córdoba, 2002, T. IV, pp. 191-202.

92 AMM CR 1651-1656 f. 5-6, Madrid, 3-XI-1651: título de gobernador, adelantado y capitán mayor; y ACMS 5613, sn: «Adelantamiento del Reino de Murcia, marquesado de Villena [...]. Razón individual de todo lo que existe en el archivo de Su Excelencia mi Señor perteneciente al Adelantamiento del Reino de Murcia desde sus principios hasta el estado presente, con todas las preeminencias, provisión de empleos, honor y otras cosas pertenecientes a dicho Adelantamiento radicado en la Excelentísima Casa de los Vélez y asimismo esta aquí toda lo perteneciente a las Alcaidías de las ciudades de Murcia y Lorca».

93 AMM 4037, $\mathrm{n}^{\circ}$ 8: copia de la real provisión de nombramiento de teniente de adelantado al conde Colonna.

${ }_{94}$ AGS GA 42, f. 68: hoja de servicios de don Juan González Salamanqués, y AHPM protocolo 2174 escribano Juan de Valcárcel y Dato, X-I-1678: carta de pago a doña Juana Mercante Merino Villafaña, viuda de don Juan González Salamanqués, por el sueldo que se le debe correspondiente al año 1676.

95 AGS CJH 1438, sn: Madrid, 4-1I-1678: minuta del sueldo de gobernador de Cartagena que ascendía a 1204 escudos al año, y AHPM protocolo 2174 escribano Juan de Valcárcel y Dato, 26-VIII-1678: carta de pago por su sueldo de marzo de 1678 .

96 AGS CJH 1445, sn: Madrid, 11-III-1683: memorial de don José de Frías, gobernador de Cartagena, solicitando que su sueldo de 300 escudos al mes se sitúe en el servicio de Millones de Murcia.

97 AGS GA 2721, sn: Cartagena, 18-XI-1686: el gobernador Figueroa al marqués de Villanueva solicitándole la plaza vacante de general de la caballería de Extremadura (adjunta memorial con servicios).

98 AHN E 1304, $\mathrm{n}^{\circ}$ 21: relación de servicios de don Antonio de Heredia Bazán, caballero de Santiago, y AHPM protocolo 2178 escribano Juan de Valcárcel y Dato, 22-II-1690: carta de pago por diversos sueldos atrasados (300 escudos al mes) desde septiembre de 1688.

Hispania, LXIII/3, núm. 215 (2003) 969-994 
1703 este cargo sería desempeñado por el también sargento mayor don Carlos de San Gil y la Justicia, caballero de San Juan, que simultáneamente absorbería el corregimiento de Murcia y Cartagena ${ }^{99}$. Tal concentración del poder delegado de la Corona en el reino de Murcia se prolongaría a partir de 1705 con el poliédrico obispo y capitán general don Luis Belluga y Moncada.

Los gobernadores de lo político y militar de Cartagena se antepusieron a las otras jurisdicciones ya presentes en la ciudad; reunieron las competencias aparejadas al título de adelantado — de hecho actuaban como su teniente- y acapararon otras sin contenido real inmediato, pero asumido progresivamente mediante el ejercicio cotidiano del mismo. De esta manera, el gobernador se fue convirtiendo en el principal transmisor al Consejo de Guerra de las novedades defensivas de la plaza y del resto del reino; en el responsable militar de la gente movilizada en los socorros a la costa, como los efectuados en 1691 y $1693^{100}$; y en un activo asistente de las peticiones del presidio de Orán, dependiente en gran parte del abastecimiento de grano y soldados que se le proporcionaba desde el reino de Murcia ${ }^{101}$.

La superposición de hasta cuatro jurisdicciones en la ciudad de Cartagena - concejo, alcalde mayor, oficiales reales del puerto y gobernador- ocasionó una lógica competencia por erigirse en el interlocutor político de la Corona. Los frecuentes conflictos de jurisdicción, al mismo tiempo que enturbiaron frecuentemente las relaciones internas, a largo plazo terminaron por asentar al gobernador en un foco de poder preeminente ${ }^{102}$. A las ya tradicionales tensiones entre el corregidor —o su teniente, el alcalde mayor-y la propia ciudad de Cartagena ${ }^{103}$, cobraron mayor notoriedad los litigios protagonizados entre el gobernador y alguno de los oficiales reales del puerto - proveedor de armadas y fronteras o castellano-; así como, también, entre el gobernador y el corregidor de Murcia, los dos delegados regios más importantes de todo el reino. En el

99 AMM AC 1703 AE 19-V-1703: carta de nombramiento de don Carlos de San Gil, y AGS GA 11, f. 33: hoja de servicios de don Carlos San Gil.

100 AMM AC 1691 AO 24-VII-1691; AC 1693 AE 14-VII-1693 (primer socorro), AE 1-VIII1693 (segundo) y AE 15-X-1693 (tercero), para las peticiones de tropas a Murcia.

${ }_{101}$ Por ejemplo, AGS GA 2679, sn: Murcia, 14-VIII-1685: el gobernador don Sebastián de Figueroa a don Juan Antonio López de Zárate, sobre levantar una compañía de 100 hombres para Orán; 2783, sn: Orán, 18-X-1688: don Antonio de Heredia al marqués de Villanueva, para acudir personalmente al socorro de Orán; la oposición de las autoridades oraníes, 2783, sn: Orán, 30-XI1688: el gobernador don Lorenzo de Ripalda al mismo, donde le señala que se considera "perjudicado en su manejo [de la plaza]».

102 «Y que la muchedumbre de jurisdicciones a que esta sujeto este corto lugar hace que ninguna tenga justo ejercicio complicándose unas con otras», AGS GA 2853, sn: Cartagena, 30-X1690: el gobernador Heredia Bazán al marqués de Villanueva.

103 Montojo Montojo, V.: El Siglo de Oro en Cartagena (1480-1640), Murcia (1993) pp. 92 94, GRANDAL LÓPEZ, A.: «Las relaciones del Concejo de Cartagena con el Estado y sus representantes a finales del siglo XVI» en Nuestra historia, Alicante, 1987, pp. 187-194, y TORNEL COBACHO, C.: El gobierno de Cartagena en el Antiguo Régimen, Murcia, 2001.

Hispania, LXIII/3, núm. 215 (2003) 969-994 
primer caso, el propósito se centraba entorno a quién correspondía la máxima autoridad militar dentro de una ciudad portuaria con un importante tránsito de tropas, un creciente comercio y en la que se encontraban diversas dependencias realengas: las casas reales y el castillo ${ }^{104}$. Por el contrario, en la segunda tipología de conflictos - corregidor vs. gobernador- la razón pasaba por conseguir acaparar el mayor espacio de relación con la Corona, como medio de promoción profesional ${ }^{105}$. No ha de extrañar, por consiguiente, que sus fricciones adquiriesen naturaleza tanto en cuestiones - en principio- de menor consideración, caso, por ejemplo, del castigo a Bartolomé Mínguez por la muerte del alférez don Juan de la Cueva, como en otras donde la legitimización de uno y otro llegaba a cuestionarse, lo que sucedería de hecho con el derecho a título de capitán a guerra ${ }^{106}$.

En esta transición hacia la consolidación de una vía ejecutiva en materia militar salió beneficiado el nuevo delegado del monarca, frente a las demás instancias que coincidían en la ciudad de Cartagena. Tanto el concejo municipal, que quedaba empequeñecido ante el poder aglutinador del gobernador ${ }^{107}$, como el corregidor, que iba reduciendo sus competencias desde varios flancos - fiscal y defensivo-, fueron los que en términos relativos perdieron mayor espacio político.

${ }^{104}$ En 1685 el gobernador don Sebastián de Figueroa se quejaba de la «ignorancia» que había hecho uso el proveedor, don Antonio Fernández de la Torre, de su particular competencia en pasar muestra a las compañías de infantería que arribaban: «lo que me pertenece diciéndole que yo debía asistir a la muestra y que sin participármelo no era materia regular ni tolerable el ejecutarlo pues el empleo empleo [sic] en que. Vuestra Majestad me ha puesto contiene esta regalía y el fuero militar la contrae en todas partes", razones que no reconocía el oficial real; para éste el gobernador "quería hallarse presente a pasar la muestra en inteligencia que estos oficios habían de estar a su orden, aunque no lo hayan estado nunca en tiempo de sus antecesores y con la presencia del Señor marqués de los Vélez [...] repitiendo que hemos de atender a lo que le pareciese y que nos ha de obligar a ello con su autoridad y violencias»; a tal grado llegó el enfrentamiento entre uno y otro, "con palabras descompuestas» entre una y otra parte, que tuvo que intervenir el duque de Veraguas, cuatralbo de las Galeras de España, venciendo «la sinrazón del proveedor»; el gobernador responsabilizaría a estos oficiales reales de «distribuirse los maravedíes que han entrado en su poder por la Real cuenta y algunas cantidades tan viciosamente que con muy poca cuenta y razón se ha dado paradero a la Hacienda de Vuestra Majestad", AGS GA 2684, sn: 24-III-1685: el gobernador al rey, y 26-III1685: los oficiales reales a don Juan Antonio López de Zárate.

105 AGS GA 2716, sn: Cartagena, 29-VII-1686: el gobernador al marqués de Villanueva, donde le indicaba que «[...] el corregidor de Murcia da muestras de tener enemiga conmigo por diferentes competencias [...]".

${ }_{106}$ AGS GA 2718, sn: Cartagena, 25-II-1686: don Sebastián de Figueroa al Consejo. Ese título, que había sido concedido en 1690 al corregidor don Fernando de Cea y Córdoba, posteriormente se señalaría que había sido para «condecorar su persona» y permanecer por «debajo de las órdenes del Adelantado Mayor", funciones que asumía el gobernador como su teniente, 2848, sn: Madrid, 12-X-1690: memorial de don Fernando de Cea; y 3122, sn: Cartagena, 4 y 26-V-1699: don Antonio Heredia Bazán a don José Pérez de la Puente.

${ }^{107}$ No es extraño que en 1693 solicitase un corregimiento propio independiente al de Murcia, AGS GA 2940, sn: Cartagena, 20-VII-1693: la ciudad al marqués de Villanueva; también, MERINo Álvarez, A.: Geografía bistórica de la provincia de Murcia, Murcia, 1981, $3^{\text {a }}$ ed., p. 413. 
Esta consolidación de la figura del gobernador contribuyó a reforzar la función militar que Cartagena iba a desarrollar después de la Guerra de Sucesión, a partir de los proyectos marítimos - especialmente el arsenal- que irían aparejados al reformismo borbónico.

\section{CONCLUSIONES}

El año 1700 no fue tanto el inicio como la continuidad de un proceso de asimilación de espacios de poder por la Corona en tierras de Castilla. Un proceso que contó con el consenso político entre las elites provinciales que obtuvieron, a cambio de su colaboración, numerosas posibilidades de retribución e integración en el mismo aparato monárquico. Esta integración social del conjunto de los castellanos en la política de la Monarquía ayudó a que el progresivo desmantelamiento de las viejas libertades castellanas, especialmente en su tradicional representación: las cortes, fuese no sólo asumido por estos mismos poderes locales, sino que, incluso, no originase importantes resistencias ante formas instituciones más directas de ejercer la coerción. La generalización del establecimiento de juntas ad hoc o el desarrollo de figuras administrativas como el superintendente y, en el caso del reino de Murcia, el gobernador de lo político y militar de Cartagena, distan de parecer un recurso coyuntural de una Hacienda permanentemente agobiada; ni, por otro lado, una excepción más o menos localista, sino dos ejemplos representativos del proceso de ordenación del poder que se fue acentuando durante el reinado de Carlos II. Estas graduales reformas incidieron en una más patente percepción de las potestades del monarca y, a posteriori, contribuyeron a concebir un renovado escenario de las relaciones políticas de la - todavía-Monarquía de los Austrias.

El programa político que Felipe $\mathrm{V}$ puso en marcha tras su acceso a la Corona española, más abrupto en un principio por las circunstancias bélicas del momento, y lógicamente más cauteloso después de la $\mathrm{Paz}$ de Utrecht, probablemente no se inspirase únicamente en fuentes francesas, aunque este modelo adquiriese cierta preponderancia formal a través de algunos de los primeros secretarios borbónicos. Estos cambios del primer reformismo dieciochesco también tenían su raíz en un desarrollo y actualización del capital político acumulado con anterioridad. Los elementos novedosos provinieron, más frecuentemente en el grado de intensidad, extensión y visualización al que se sometió la capacidad de intervención ya lograda.

De este modo, en la realidad de un vecino de la Corona de Castilla de principios del siglo XVIII, las opciones representadas por el duque de Anjou o el archiduque Carlos quizás no supusiesen tanto dispares alternativas políticas incidentes en detracciones futuras, como presumiblemente a razones más ambientales: la participación en un movimiento activo de opinión construido y exteriorizado a través de múltiples intereses clientelares; o a decisiones individuales/colectivas inducidas por diversos canales de movilización social. 